66 STAN. L. REV. ONLINE 9

April 29, 2013

\title{
DODD-FRANK REGULATORS, COST-BENEFIT ANALYSIS, AND AGENCY CAPTURE
}

\author{
Paul Rose \& Christopher J. Walker*
}

INTRODUCTION

The Dodd-Frank Wall Street Reform and Consumer Protection Act (Dodd-Frank) has raised the stakes for financial regulation by requiring more than twenty federal agencies to promulgate nearly 400 new rules. ${ }^{1}$ Scholars, regulated entities, Congress, courts, and the agencies themselves have all recognized-even before Dodd-Frank - the lack of rigorous costbenefit analysis in the context of financial rulemaking. ${ }^{2}$ The D.C. Circuit has struck down several financial regulations because of inadequate cost-

\footnotetext{
* Associate Professor of Law and Assistant Professor of Law, respectively, Michael E. Moritz College of Law, The Ohio State University.

1. Pub. L. No. 111-203, 124 Stat. 1376 (2010) (codified as amended in scattered sections of the U.S. Code); see Deconstructing Dodd-Frank, N.Y. Times (Dec. 11, 2012), http:/Www.nytimes.com/interactive/2012/12/11/business/Deconstructing-Dodd-Frank.html (citing law firm report that 398 rules are required by Dodd-Frank)

2. See, e.g., PaUl Rose \& Chistopher J. Walker, Ctr. For CaPital Mkts. COMPETITIVENESS, U.S. CHAMBER OF COMMERCE, THE IMPORTANCE OF COST-Benefit ANALYSIS IN FINANCIAL REGULATION 6-11 (2013), available at http://ssin.com labstract=2231314. To be sure, the relevant parties do not agree that independent agencies are legally required to conduct a formal cost-benefit analysis, as such agencies are not subject to the executive orders requiring cost-benefit analysis. Instead, the D.C. Circuit has held that the Administrative Procedure Act and agencies' governing statutes require them to consider costs and benefits. See id. at 6-9, 24-36; see also cases cited infra note 3. In March 2012, the SEC responded to criticisms about inadequate cost-benefit analysis by issuing a guidance memorandum that in effect embraces the executive's cost-benefit analysis framework while maintaining that "[n]o statute expressly requires the Commission to conduct a formal cost-benefit analysis as part of its rulemaking activities." Memorandum from the SEC Div. of Risk, Strategy, \& Fin. Innovation and the SEC Office of the Gen. Counsel to the Staff of the Rulewriting Divs. \& Offices 3-4 (Mar. 16, 2012), available at http:/www.sec.gov/divisions/riskfin/rsfi_guidance_econ_analy_secrulemaking.pdf; see also ROSE \& WALKER, supra, at 34-36 (comparing SEC and executive agency approaches).
} 
benefit analysis, with three more challenges to be decided this summer. ${ }^{3}$ Members of Congress have introduced legislation to address this problem, including a call for the President to intervene to require more exacting economic analysis. ${ }^{4}$ Regulated entities and investor protection groups are vigorously debating whether (and how) financial regulators should engage in cost-benefit analysis, as are a variety of policymakers, academics, and commentators.

Absent from these debates, however, is a serious discussion of the importance of cost-benefit analysis in promoting good governance and democratic accountability. This Essay seeks to fill that void. The lack of attention to accountability is particularly troubling in the Dodd-Frank context, where most regulators are independent agencies and thus less democratically accountable via presidential oversight. In particular, independent agencies are not required to submit proposed rules and accompanying economic analyses for presidential review. Nor are their high-ranking officials subject to plenary presidential removal authority. Without another means of accountability - e.g., a robust cost-benefit analysis embedded in notice-andcomment rulemaking - independent agencies are more vulnerable to agency capture.

This Essay argues that Dodd-Frank regulators should consider more seriously the democratic accountability concerns at play when regulating the financial markets. And those who regulate the regulators (via statutory command, executive order, or judicial review) should pay more attention to the good governance rationales for cost-benefit analysis when deciding

3. See Bus. Roundtable v. SEC, 647 F.3d 1144, 1148-49 (D.C. Cir. 2011) (striking down proxy access rule because the SEC "inconsistently and opportunistically framed the costs and benefits of the rule"); Am. Equity Inv. Life Ins. Co. v. SEC, 613 F.3d 166, 167-68 (D.C. Cir. 2010) (striking down fixed indexed annuities rule because "the SEC failed to properly consider the effect of the rule upon efficiency, competition, and capital formation"); Chamber of Commerce v. SEC, 412 F.3d 133, 136 (D.C. Cir. 2005) (striking down mutual fund board independence rule because the SEC "violate[d] the APA by failing adequately to consider the costs mutual funds would incur in order to comply with the conditions" it adopted). As alluded to above, there are also three pending cases that challenge the adequacy of the financial regulators' cost-benefit analysis. See Am. Petroleum Inst. v. SEC, No. 121398 (D.C. Cir. argued Mar. 22, 2013) (challenging extractive industries rule); Investment Co. Inst. v. U.S. Commodity Futures Trading Comm'n, No. 12-5413 (D.C. Cir. to be argued May 6, 2013) (challenging investment companies oversight rule); Nat'l Ass'n of Mfrs. v. SEC, No. 12-1422 (D.C. Cir. to be argued May 15, 2013) (challenging conflict minerals rule).

4. Independent Agency Regulatory Analysis Act of 2012, S. 3468, 112th Cong. (2012) (proposing legislation "[t]o affirm the authority of the President to require independent regulatory agencies to comply with regulatory analysis requirements applicable to executive agencies"); see also Financial Regulatory Responsibility Act of 2011, S. 1615, 112th Cong. (2011), reintroduced as S. 450, 113th Cong. (Mar. 5, 2013); SEC Regulatory Accountability Act, H.R. 2308, 112th Cong. (2011), reintroduced as H.R. 1062, 113th Cong. (Mar. 12, 2013). 
whether and how to encourage Dodd-Frank regulators to engage in more rigorous and transparent economic analysis.

\section{TRADitional RATIONALES FOR COST-BENEFIT ANALYSIS}

For over three decades - under both Democratic and Republican administrations - cost-benefit analysis has been a fundamental regulatory tool in the modern administrative state. Over the years, Congress and various Presidents have taken a number of steps to require federal agencies to engage in cost-benefit analysis when deciding how to regulate. Cost-benefit analysis, as developed by the last five Presidents, instructs that an agency should "adopt a regulation only upon a reasoned determination that the benefits of the intended regulation justify its costs" and should "tailor its regulations to impose the least burden on society." "The traditional rationales for costbenefit analysis have focused on promoting more rational regulatory decisionmaking and thus more efficient regulation.

Cost-benefit analysis furthers these interests in a number of ways. First, it assists in ensuring that regulatory efforts produce a net positive effect on society, which should be a fundamental goal of all regulation. Choosing whether and how to regulate is generally a question of evaluating tradeoffs. Cost-benefit analysis requires an agency to consider the various economic effects of a particular regulation as opposed to possible alternatives, including the alternative of no regulation at all.

Moreover, cost-benefit analysis reduces the risk of unintended consequences by forcing the agency to consider all costs and benefits as well as the range of regulatory alternatives. Regulators systematically overestimate the likelihood of events that come easily to mind-especially recent, highprofile events where regulation failed; indeed, Dodd-Frank is what Larry Ribstein would characterize as a "bubble law" that is particularly susceptible to overestimation of risk. ${ }^{6}$ Cost-benefit analysis forces the agency to focus not only on preventing a future catastrophe but also on any other consequences of the proposed regulation. In so doing, the agency forces itself

5. Exec. Order No. 12,866, 58 Fed. Reg. 51,735 (Sept. 30, 1993); accord Exec. Order No. 13,563, 76 Fed. Reg. 3821 (Jan. 18, 2011); see also OFFCE OF MGMT. \& BudGET, CirCular A-4: Regulatory ANAlysis (2003), available at http://www.whitehouse.gov $/$ sites/default/fíles/omb/assets/omb/circulars/a004/a-4.pdf. See generally Peter M. Shane, Political Accountability in a System of Checks and Balances: The Case of Presidential Review of Rulemaking, 48 ARK. L. REV. 161, 176-78 (1995) (comparing Reagan and Clinton executive orders imposing cost-benefit analysis on executive agencies).

6. See Larry E. Ribstein, Bubble Laws, 40 Hous. L. Rev. 77, 78-79 (2003); see also, e.g., CAss R. Sunstein, Risk and Reason: SAFETy, LAW, AND THE ENvironmENT 22-26 (2002); Cass R. Sunstein, Congress, Constitutional Moments, and the Cost-Benefit State, 48 Stan. L. Rev. 247, 261-62 (1996). But see John C. Coffee, Jr., The Political Economy of Dodd-Frank: Why Financial Reform Tends to Be Frustrated and Systemic Risk Perpetuated, 97 CORNELL L. REV. 1019, 1025-26 (2012) (criticizing bubble law theory). 
to quantify risks and thus reduces the likelihood that cognitive biases negatively affect regulatory efforts.

Finally, cost-benefit analysis encourages regulators to properly allocate limited resources. Regulators must not merely ensure that regulatory benefits justify the costs; they must make the most efficient use of scarce resources. If an agency can produce comparable outcomes in multiple ways, it should choose the one that imposes the smallest net cost to society, and to the agency itself. Without some form of cost-benefit analysis, the agency has no grounds to make such a judgment. In sum, by requiring regulators to account for the anticipated costs and benefits of proposed regulations, costbenefit analysis increases the likelihood that rules will take into account all relevant considerations, produce net positive outcomes, avoid unintended consequences, be more cost-effective than comparable alternatives, and distribute resources efficiently.

Criticisms of cost-benefit analysis have similarly focused on efficiency and rational decisionmaking. Some critics have challenged the method's ability to accurately calculate costs and benefits as well as the regulators' expertise to make such calculations. In the financial markets context, critics have renewed longstanding arguments that cost-benefit analysis is unnecessarily costly and time-consuming. There are, of course, also well-traversed ethical and moral critiques of cost-benefit analysis. ${ }^{7}$ Others have objected to cost-benefit analysis on decisionmaking grounds because it "closes off opportunities for public debate, and substitutes control by a new breed of 'experts' who subtly manipulate the evaluation so that it conforms to the procedures of the market-place."

We have explored these criticisms elsewhere and concluded that many arguments against cost-benefit analysis developed in other contexts do not apply with equal force (if at all) in the context of financial regulation. ${ }^{9}$ For instance, whatever the value of ethical arguments against the use of costbenefit analysis in the context of environmental, safety, or other regulations,

7. For efficiency criticisms generally, see, for example, Thomas O. McGarity, Professor Sunstein's Fuzzy Math, 90 GEO. L.J. 2341, 2344-45 (2002) (discussing "daunting scientific uncertainties" in cost-benefit analysis). For efficiency criticisms specific to financial regulation, see, for example, BetTer MKts., Setting the ReCord Straight on Cost-Beneft ANALYSIS AND FINANCIAL REFORM AT THE SEC 36-38 (2012), available at http:/www.bettermarkets.com/sites/default/files/Setting The Record Straight.pdf. For ethical and moral criticisms, see, for example, Jeffrey L. Harrison, Egoism, Altruism, and Market Illusions: The Limits of Law and Economics, 33 UCLA L. REV. 1309, 1317 (1986); Lisa Heinzerling, Regulatory Costs of Mythic Proportions, 107 Y ALE L.J. 1981, 2049 (1998); and Martha C. Nussbaum, The Costs of Tragedy: Some Moral Limits of Cost-Benefit Analysis, 29 J. LEGAL STUD. 1005 (2000).

8. Robert C. Zinke, Cost-Benefit Analysis and Administrative Legitimation, 16 POL'Y StUD. J. 63, 73 (1987) (quoting David Dickson et al., The Cost-Benefit Swindle Puts Dollar Signs on Human Health, IN THESE TIMES, May 13-19, 1981, at 13, 13) (internal quotation mark omitted).

9. See ROSE \& WALKER, supra note 2 , at 16-24. 
financial regulation is less likely to implicate thorny questions of placing a value on human life or comparing tangible economic costs with less tangible environmental costs, such as the value of wildlife preserves or endangered species. There will still be debates about how to quantify different costs and benefits, but the costs and benefits at issue in financial regulation are generally economic and thus quantifiable without having to engage in valuing noneconomic costs or benefits.

\section{GOOD GOVERnANCE RATIONALES FOR COST-BENEFIT ANALYSIS}

Whereas the efficiency and rational decisionmaking arguments are front and center in the debates about the use of cost-benefit analysis in financial regulation, the good governance rationales are seldom seen or heard. Yet they are similarly, if not more, important.

To appreciate the value of cost-benefit analysis in promoting good governance, consider the nature of federal regulation: Article I of the Constitution provides that "[a]ll legislative Powers herein granted shall be vested in a Congress[,]" ${ }^{\prime 10}$ but in practice Congress delegates substantial rulemaking authority to federal agencies. Unlike members of Congress, agency officials are not elected. This means that citizens, who are bound by the force of law of agency rules, neither directly select these administrators nor have the power to directly vote them out of office. As the federal bureaucracy has grown over time, the President has assumed oversight responsibility for much agency rulemaking. Nonetheless, tension remains between the modern regulatory state and our democratic values.

Because federal agency officials wield considerable power but acquire their positions by appointment rather than directly through the democratic process, their regulations raise concerns of democratic legitimacy and accountability. Cost-benefit analysis helps alleviate those concerns by making agency decisionmaking more transparent to the public and to elected officials who can exercise control over the agencies. Among the stated goals for the use of cost-benefit analysis by executive agencies is "to make the [regulatory] process more accessible and open to the public." 11 Cost-benefit analysis requires an agency to attempt to quantify its reasoning processrevealing which aspects of a problem the agency has taken into account. One can challenge the agency's calculations or even its choices about which factors count in the decisionmaking process. "Armed with this information, the well-disposed president can scold, threaten, or punish agencies that do not produce welfare-maximizing regulations." ${ }^{22}$ Indeed, as Eric Posner has maintained, "[t]he purpose of requiring agencies to perform cost-benefit

10. U.S. CONST. art I, § 1.

11. Exec. Order No. 12,866, 58 Fed. Reg. 51,735 (Sept. 30, 1993).

12. Matthew D. Adler \& ERIC A. Posner, New Foundations of Cost-BeneftT ANALYSIS 111 (2006). 
analysis is not to ensure that regulations are efficient; it is to ensure that elected officials maintain power over agency regulation." 13

A second good governance value of cost-benefit analysis is that it leverages the expertise of the regulators and, ideally, applies it in a neutral fashion to a particular regulatory problem. ${ }^{14}$ Agencies do not begin rulemaking on a blank slate, surveying all of the possible solutions to a problem and seeking to choose the best. They begin with a mandate from Congress and, often, strong policy preferences from the President. But Congress does not delegate rulemaking authority to agencies simply to allow the President to shape the details of the statutory scheme, especially in the case of independent agencies. Congress does so at least in part on the theory that agencies will bring to bear technical expertise that Congress lacks. ${ }^{15}$

Cost-benefit analysis facilitates the exercise of this expertise by providing a framework that insulates the agencies from powerful political pressures. One way it does so is by focusing on the objective effects of the regulation. As financial markets and attendant regulatory interventions increase in complexity, Dodd-Frank regulators' expertise-and the cost-benefit analysis methodologies that leverage the exercise of this expertise-takes on commensurately increasing importance.

\section{AGENCY INDEPENDENCE AND CAPTURE}

Cost-benefit analysis also furthers the important good governance aim of avoiding agency capture by regulated parties. This objective is particularly important in the independent agency context, where the President cannot exert the same degree of control over agency decisionmaking.

Regulated parties can and should provide input into the development of regulations. But the possibility exists that private actors-whether those who are or will be subject to regulation, or others who stand to gain or lose from particular regulatory action-will gain undue influence over the regulators. Such agency capture can occur for many reasons, including the revolving-door phenomenon whereby regulators anticipate taking or returning to jobs in industry and fear alienating the entities they regulate. ${ }^{16}$ In the

13. Eric A. Posner, Controlling Agencies with Cost-Benefit Analysis: A Positive Political Theory Perspective, 68 U. CHI. L. REV. 1137, 1141 (2001); accord Eric A. Posner, CostBenefit Analysis as a Solution to a Principal-Agent Problem, 53 ADMIN. L. REV. 289, 291-92 (2001).

14. See, e.g., John F. Manning, Constitutional Structure and Judicial Deference to Agency Interpretations of Agency Rules, 96 CoLuM. L. REv. 612, 680-81, 686-90 (1996).

15. See, e.g., Peter H. Aranson, Ernest Gellhorn \& Glen O. Robinson, A Theory of Legislative Delegation, 68 CORNELL L. REV. 1, 6-7 (1982).

16. See, e.g., Rachel E. Barkow, Insulating Agencies: Avoiding Capture Through Institutional Design, 89 TEX. L. REV. 15, 23 (2010); Richard B. Stewart, The Reformation of American Administrative Law, 88 HARV. L. REV. 1669, 1713-14 (1975). See generally

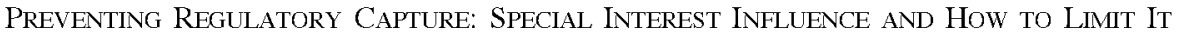


financial regulation context, agencies face pressure not only from those they regulate, but also from interest groups that represent the interests of investors and others who may benefit from, or be hurt by, a particular regulation. And-though perhaps not the classic form of capture-there may be undue pressure put on the agency by high-ranking agency officials with particular policy agendas, or by the politicians who helped those officials obtain their positions within the agency.

Cost-benefit analysis does not by itself prevent such influence. But, when coupled with notice-and-comment rulemaking, the resulting transparency in agency decisionmaking should substantially disarm the threat of agency capture. ${ }^{17}$ Notice-and-comment cost-benefit analysis provides a significant protection by requiring the agency to reveal the factors that underlie its analysis. If interest group pressure has distorted the agency's calculations of costs and benefits, the analysis is likely to reflect such influence and provide Congress, the President, the courts, and the public at large with an opportunity to demand course correction. Moreover, such transparency raises the cost of attempts at undue influence, as regulators should be less willing to adopt less efficient positions if they know that the origin of those positions will be revealed.

These protections against agency capture are particularly important in the Dodd-Frank context, where most regulators are independent agencies that are further removed from presidential control than traditional executive agencies. For instance, the heads of independent agencies are not subject to plenary presidential removal authority. And, unlike executive agencies, their rulemaking processes are not subject to presidential oversight via review by the Office of Information and Regulatory Affairs within the President's Office of Management and Budget. ${ }^{18}$ Instead, the ultimate defense against independent agency capture is the public nature of the process itself, with the threat of congressional (and perhaps judicial) oversight and correction.

In striking down an SEC rule for inadequate cost-benefit analysis, the D.C. Circuit seems to have recognized this value, remarking that the agency must "apprise itself - and hence the public and the Congress-of the economic consequences of a proposed regulation before it decides whether to

(Daniel Carpenter \& David Moss eds., forthcoming 2013), available at http://ww.tobinproject.org/books-papers/preventing-capture.

17. Cf. David Fontana, Reforming the Administrative Procedure Act: Democracy Index Rulemaking, 74 FORDHAM L. REV. 81, 91 (2005) (explaining that transparency during noticeand-comment rulemaking "makes it much more difficult for there to be agency capture").

18. See Rose \& WALKER, supra note 2, at 4-6; see also Elena Kagan, Presidential Administration, 114 HARV. L. REV. 2245, 2331-32 (2001) (explaining that presidential oversight "establishes an electoral link between the public and the bureaucracy, increasing the latter's responsiveness to the former"). 
adopt the measure." ${ }^{\prime 19}$ As Henry Manne has observed, cost-benefit analysis in financial regulation serves the important democratic function of making "the discussion of new regulations more open to truly informed community comment as opposed to special-interest pleading" and assures the public that "their comments will be examined by sensible and knowledgeable experts and not bureaucrats interested mainly in the political implications of a new proposal. ${ }^{20}$ Without conducting a robust cost-benefit analysis that is made public and transparent via notice-and-comment rulemaking, defenses against agency capture are undermined.

\section{CONCLUSION}

Despite decades-long bipartisan support for cost-benefit analysis, regulators of financial markets (whose rulemaking is not subject to presidential review) have been slower and more haphazard in adopting this method than their executive agency counterparts. Especially now that Dodd-Frank has exponentially increased the amount of financial rulemaking and considerably raised the stakes for regulating the financial markets, financial regulators can and should ground their rulemaking in a proper cost-benefit analysis to arrive at more rational decisionmaking and more efficient regulation. Conducting a rigorous cost-benefit analysis via notice-and-comment rulemaking also makes for good governance. Without such public transparency-especially in the context of independent agencies-democratic accountability suffers, and agency capture becomes a greater threat.

For these reasons, the lack of attention to good governance in the current debates about cost-benefit analysis in financial regulation is particularly disconcerting. Dodd-Frank regulators must grapple with these accountability issues themselves. If they do not (or continue to do so inadequately), Congress, the President, or even the courts should, and likely will, intervene to encourage more exacting and transparent economic analysis. As part of that intervention, these regulators of the regulators can and should impose more democratic accountability over the independent agencies Dodd-Frank has charged with the daunting task of regulating the financial markets.

19. Chamber of Commerce v. SEC, 412 F.3d 133, 144 (D.C. Cir. 2005) (emphasis added).

20. Henry G. Manne, Economics and Financial Regulation: Will the SEC's New Embrace of Cost-Benefit Analysis Be a Watershed Moment?, REgulation, Summer 2012, at $20,23$. 